\section{Care-full research ethics in multispecies relations on dairy farms}

cultural geographies

2021, Vol. 28(3) 479-493

(C) The Author(s) 2021

(c) (i)

Article reuse guidelines: sagepub.com/journals-permissions DOI: I0.I I77/|474474020987248

journals.sagepub.com/home/cgj

(9SAGE

\author{
Annika Lonkila \\ University of Eastern Finland, Finland \\ Finnish Environment Institute, Finland
}

\begin{abstract}
Although ethical questions are at the core of more-than-human geographies, more attention needs to be paid on researchers' ethical responsibilities to more-than-human research subjects in social scientific research. In this paper I critically analyze my empirical work on Finnish dairy farms from the perspective of multispecies research ethics. I suggest that the concept of care is useful in understanding more-than-human research ethics. Attending to the needs of others can work as a starting point for making difficult ethical decisions in the field. However, in contested moments, different needs are often in conflict. Here, situated ethical responses might be needed in relation to the practices of fieldwork, for example to avoid causing harm to research subjects. Importantly, researchers have to care for their research subjects also through their analysis; addressing the questions related to research ethics also in terms of knowledge politics. When the ethics of care is complemented with the notion of ethics of exclusion, it has potential to tease out broader responsibilities both in interactions and knowledge about other animals and morethan-human research settings.
\end{abstract}

\title{
Keywords
}

care, ethics of exclusion, fieldwork, interference, more-than-human, research ethics

\section{Introduction}

In the last few decades, the posthumanist, more-than-human turn has transformed the conventions and practices of Cultural Geography. Specifically advancements in innovative, participatory and more inclusive research methods ${ }^{1}$ in the emerging field of posthuman ${ }^{2}$ and more-than-human geographies ${ }^{3}$ have contributed to epistemological and ontological openings, demanding that other animals are taken seriously as partners in shared spaces, co-producing knowledge and research. Here, more-than-human agency is understood as relational and entangled, emerging from complex, 
heterogeneous networks of 'co-constituted' actors. ${ }^{4}$ In decentering the human, critical multispecies geographies have also faced the task of developing more contextual and situated ethical responsibilities, pushing forward forms of relational ethics that stem from the embodied encounters between entangled, more-than-human beings. ${ }^{5}$

More-than-human geographers have also been interested in exploring how to implement the notion of relational ethics into research ethics, especially in relation to the laboratory. ${ }^{6}$ These studies have specifically discussed how more situated and embodied ethics can meaningfully complement institutional and legal ethical guidelines. The idea is that rather than confining ethical issues to specific procedures such as informed consent, these issues need to be situated in relation to other spaces and agents. ${ }^{7}$ In this paper the focus is on empirical settings where institutional ethical guidelines concerning research on animals are less abundant - empirical research on animals in social sciences. In social sciences, multispecies research projects often involve participatory observation or other similar, non-invasive methods of study. I argue that situated ethics can also be very helpful in mapping out the more-than-human ethical responsibilities of such research projects.

In this paper I draw from my own empirical experiences: conducting my $\mathrm{PhD}$ in the field of Human Geography, hoping to do observational and participatory empirical work on dairy farms, I found ethical guidelines suited to multispecies research to be lacking. Generally, the more invasive the research practices are, the more clearly defined the research ethical guidelines are. ${ }^{8}$ Yet, embarking on fieldwork, I understood that there existed a vast range of tacit, largely unwritten practices that supported the ethical execution of more-than-human research. This paper is an exploration into putting these practices into words, and asking whether they can be perceived as practices of research ethics.

My research focused on the changing practices of dairy cattle breeding in Finland, and the data, collected in 2015-2016, consists of interviews with 19 dairy farmers and 11 farm visits. ${ }^{9}$ During the farm visits, I would follow the farmer and cows in their work in the cowshed. The focus of the research was on the impacts of breeding on cattle, as well as human-cattle relations and cattle behavior. I spent 1 day on each farm. Officially, my $\mathrm{PhD}$ thesis was only guided by the general Finnish guidelines of social scientific research involving human research subjects. ${ }^{10} \mathrm{My}$ ethical responsibilities for human research subjects involved not causing harm for them, and this included, by proxy, cows as their property. No ethical review was required due to my interest to work with other research subjects than humans. The Finnish Act on the Protection of Animals Used for Scientific of Educational Purposes is specifically defined to not apply non-invasive research practices that are 'not likely to cause pain, suffering, distress of lasting harm equivalent to, or higher than, that caused the introduction of a needle in accordance with good veterinary practice' ${ }^{11}$ Had I been conducting my research in the field of livestock sciences, however, I could have subjected my thesis to a voluntary ethical review. In Finland, this review process is directed specifically at research that does not fall under the law on animal research; research that causes less harm than a pin-prick. The ethical review board evaluates how participation in the research influences the everyday life of the animal and its owner, for example if the research setting restricts the movement of the animal or alters its diet. Participant observation is also mentioned as a potential impact. ${ }^{12}$ Although the empirical research settings can be quite similar in some livestock sciences projects as in more-than-human geographies, the institutional setting may influence whether the ethical aspects are reviewed.

Beyond exploring the researcher's relationship with non-human research subjects, I was also interested in teasing out the tensions and conflicts involved in research that includes multiple groups of research subjects, in this case from human and bovine species. My focus on both farmers and cattle made it fundamentally important that my research ethical responsibilities would always include both of these groups. Yet I recognized that there existed many tensions between these 
groups, potentially creating tension also for research ethics. To makes sense of this tension, in the next section of the paper, focusing on the theoretical foundations of the paper, I turn to the concept of feminist ethics of care. The goal of the ethics of care is understood as an attempt to 'deal with conflict, disagreement, and ambivalence rather than attempting to eliminate it' ${ }^{13}$ I suggest that in order to craft care-full research ethics, the ethics of care are meaningfully complemented by the perspective of ethics of exclusion. I go on to examine how such care-full research ethics might look like in practice. In the following empirical sections, I map out my experiences in attempting to attend to my relational ethical responsibilities as a researcher, both in the field and in analysis. I introduce the concept of material and analytical interferences, built on exercising my capacity to respond better to my research subjects, as well as attempts to tease out responsibilities related also to what becomes excluded in our relations with more-than-human others in the research practice.

\section{Situated ethico-politics of care in multispecies spaces}

A burgeoning interest in the topic of care has swept various academic disciplines in recent decades. Building on the work of feminist scholars Noddings, ${ }^{14}$ Gilligan, ${ }^{15}$ and Tronto, ${ }^{16}$ care has been explored also in the fields of geography, ${ }^{17}$ science and technology studies, ${ }^{18}$ and human-animal studies, ${ }^{19}$ among many others. Early feminist interest in care stemmed from the desire to pay attention to work performed by women, and especially mothers, within the home sphere. According to Fisher and Tronto's ${ }^{20}$ famous definition, care highlights the interdependency of all lively beings, consists of practices that seek to "maintain, continue and repair our "world" so that we can live in it as well as possible'. Fisher and Tronto ${ }^{21}$ go on to emphasize that the world in question includes all 'we seek to interweave in a complex, life sustaining web'. It is the nature of care work to be undervalued and invisible, and much of the academic interest in care stems from the hope to change this, to highlight the value of care as a fundamental part of all relations and in the continued maintenance of a more liveable world.

Importantly, caring is not something only humans do - caring relations inescapably entangle humans with nonhuman others. We care for both human and non-human others, and those others care for us - from our pets, the microbes within our guts, to the earth itself. In our world(s) consisting of relations between heterogeneous more-than-human things and beings, in caring for and about others, we create relations with them. ${ }^{22}$ Care is always a 'shared accomplishment'. ${ }^{23}$ Thus, care theory draws from an understanding of relational agency, a concept that has also been developed within the fields of Science and Technology Studies, agential realism, and new materialism, where the webs of relations between human and non-human actors are understood to be 'flat' and horizontal. ${ }^{24}$ Actors are perceived to be continuously co-constituted by more-than-human others, in an ongoing process of 'material-semiotic becoming'. 25

A theory of care argues that the relational understanding of agency has fundamental implications for how we understand ethics and moral responsibilities. The question is, what do entangled forms of agency mean for entangled forms of responsibility? A theory that is based on a relational notion of agency is fundamentally in conflict with theories highlighting individual rights and responsibilities. ${ }^{26}$ An ethics of care was developed specifically as a response to liberal theories of universal rights, highlighting the need to figure out situated solutions to particular problems, attending to their contextual and political contingencies. ${ }^{27}$ Rather than searching for abstract moral rules applicable for a society of autonomous and rational equals, an ethics of care highlights relationality, dependability, sympathy and compassion. ${ }^{28}$ An ethics of care has also been analyzed as alternative to the theory of animal rights. ${ }^{29}$

The lack of moral rules does not mean that an ethics of care cannot lead to obligations. The difference is that the responsibilities inherent to care are not forced upon beings externally, but instead 
stem from embodied relating. The idea is that responsibilities emerge from learning from situated encounters with human and non-human others, instead of interpretations based on assumptions. ${ }^{30}$ Puig de la Bellacasa ${ }^{31}$ has called care a 'non normative obligation', in that it obliges us to continue to foster life. In other words, care forces us to reckon with the fact that our way of living and being in the world is dependent on others. Caring relations aim not only to enable survival, but the building of more flourishing relations, worlds, and futures.

An ethics of care has also been criticized. It has been faulted for its insistence in refusing to issue ethical codes of action, as well as for its inapplicability across scales. If morality is rooted in embodied relations, how to care for those at a distance? Geographies of responsibility and care have specifically tackled the question of interdependency in cosmo-political relations on a larger scale. ${ }^{32}$ Geographers have argued that because the relations in the world are globalized, we are ethically bound also to distant strangers. ${ }^{33}$ Rather than asking 'should we care for those that are distant', we might see ourselves as responsible to explore how to 'cultivate our emotional sensitivities' in order to do so. ${ }^{34}$

Moral philosophers have focused on the lack of ethical codes of action within an ethics of care, and questioned how care theory holds in the face of conflict. Garner ${ }^{35}$ has queried: whose needs and desires should we choose to care for when there is a conflict of interests? Donovan explores this question in the context of clinical animal research, where the needs of humans and other animals are in obvious conflict. Following Donovan, the answer can be found in a critical, empathetic, and materially specific exploration of the context, sensitized to power relations. She states that such "lifeboat hypotheticals [. . . ] abstract so egregiously from the particulars of any given situation as to hopelessly distort it." Instead, we should focus our intellectual efforts in eradicating the practices of violence and harm. Donovan ${ }^{36}$ argues that the conflicts described can nearly always be negotiated, settled as "both/ands rather than either/ors". Nonetheless, the question remains: what happens when tensions and conflicts persist; when care for one will inevitably result in pain and suffering for another?

Scholars in the field of Science and Technology Studies have specifically maintained that an ethics of care should not be an attempt at harmony, as care is by nature never innocent. ${ }^{37}$ In this tradition, care is fundamentally seen as a negotiation about the coexistence of different values. ${ }^{38}$ It follows that the desires and needs of some subjects will come to be favored over those of others this tension cannot, and need not, be explained away. For example, the needs of beings whose capacity to feel pain we do not yet understand must be weighed against those organisms we know better. Scale also matters: how to care for ticks, or microbes? In many instances, care for one may involve death for another. For example, in conservation, care for a protected species may lead to the eradication of an invasive species. ${ }^{39}$ This inevitably leads to ethical ambivalence: care is not a 'moralistic feel-good attitude', ${ }^{40}$ and the 'dark side' of care is always present.

The ethical ambivalence always inherent in care may also be used to justify practices such as clinical animal research, but only when coupled with attempts to 'find better, more careful ways of undertaking research in the face of a situation where there are no easy, fair, or right solutions' ${ }^{41}$ For Haraway, a crucial part of ethical laboratory work is an embodied and experimental sharing of suffering between the technician and the animal. The point is learning to live with the fact that our way of living and being in the world may be dependent on the suffering of others, as well as ourselves. ${ }^{42}$ The contribution of this theoretical tradition to ethics is that living with both care and suffering must be dependent on our capacity to take responsibility for the suffering we inevitably cause.

Furthermore, scholars have recently begun to question how far our responsibility for suffering extends. Are our responsibilities to others restricted to our close somatic relations with them, or should we also be concerned with how those relations have come to be? Here, I turn to the work of Gregory Hollin, Isla Forsyth, Eva Giraud, and Tracey Potts in exploring Donna Haraway's 
engagement with the work of Barad. ${ }^{43}$ Hollin et al. ${ }^{44}$ turn specific focus on the notion of situated (multispecies) ethics set forward by Haraway, built on Barad's notion of agential realism. Haraway bases her ethical theory on Barad's notion of agential cuts. In these cuts between agents, subjectobject relations are set in materially specific and determined manner. For Haraway, multispecies encounters can lead to the redistribution of agency in ethically significant ways, depending on how things are 'cut'. As mentioned, if and when these encounters involve violence, actors must take responsibility for it.

Hollin et al. ${ }^{45}$ are saying something different. They argue that Barad's theory extends ethical responsibility to how our practices and relations come to form such agential cuts. Thus, in addition to being responsible for the consequences of our relations with others, we also have to take responsibility for how those relations have come to be - in the relations and practices that precede them. According to Barad, in agential cuts, things congeal 'as they are'. Sometimes those cuts involve violent exclusions. Developing an 'ethics of exclusion', Hollin et al. turn attention to how certain ontological possibilities come to be foreclosed at the cost of foregrounding others. The idea behind 'ethics of exclusion' is that by focusing only on relations and entanglements, we can sometimes overlook the dis-entanglements that have preceded them and the forms of relations and entanglements that continue to be excluded out of existence through the cuts performed. What are the ethical obligations that emerge from cutting things in a specific way, at the expense of other ways of being? This approach pushed forward a critical approach to care: can care be harnessed not in the fostering of life but also in the fostering of commodification or death? This question highlights that attention to care should also extend to the histories, contexts, and exclusions that constitute caring encounters. ${ }^{46}$

\section{Care-full research ethics in practice}

The idea that an ethics of care can be applied also to research ethics is not new by any means. A feminist ethic of care has focused especially on reflexivity in research practice, coupled with a political analysis of power within relations between actors. ${ }^{47}$ This takes the shape of rejecting the notion of 'value-free' research as well as the idea that the researcher is an impartial interpreter or witness to the research setting, rather than an active - and responsible - participant. The characteristics of care as research practice have been seen to include, for example, informal contexts, an emphasis on contextual reasoning, highlighting the responsibilities to others as well as ourselves, an acceptance of inevitable dependencies, and valuing and maintaining connections between individuals rather than breaking them. ${ }^{48}$ At the same time, care-full research ethics cannot be preemptied into reflexivity, or even exclusively into the researcher's responsibilities. As care is not unidirectional, but always relational, care-full research practices and responsibilities also cannot be one-sided. Care as research ethics takes shape as relations that are sympathetic and attentive to the needs and desires of others. Through its attention to the tacit and mundane practices that shape relations, care allows for paying attention to the 'microethics' that fill the spaces in meetings between bodies. ${ }^{49}$ At the same time, it is not about attempting to eliminate conflict or disagreement, but about learning to deal with it. ${ }^{50}$

Care also has epistemological value in research practice. Care is an obligation to know more about the object of our care, to engage in cultivating 'deep contextual and critical knowledge' about them..$^{51}$ This knowledge simultaneously places us at stake in the world and demands that we be held accountable. ${ }^{52}$ Through situated multispecies encounters, we can learn to better understand how nonhuman needs are articulated..$^{53}$ Moore and Kosut, ${ }^{54}$ exploring human-bee entanglements, state that 'intra-species mindfulness' is required for human researchers to de-center themselves as interlocutors to other species. Researchers can work to create space for other animals to impose their own 
ethical 'requirements', to 'speak back' to the research in order to influence the research process and its assumptions. ${ }^{55}$ This of course applies also to human research subjects. In my work, both farmers and cows at various points re-directed my research questions and practices in ways that also had ethical implications. The researcher's ability to respond is crucial here. I have found useful Donna Haraway's ${ }^{56}$ concept of 'response-ability', a way of cultivating the capacity to attend and respond to others in a relational 'praxis of care and response. . . in ongoing multispecies worlding on a wounded Terra'. Crucially, the capacities to respond are not the same for all, or for all relations.

Thus, it is crucial to come to terms with the non-innocence of care as research practice. The relations within research projects include care, but 'our cares also perform disconnection' ${ }^{57}$ We cannot care for all, all the time. The problem here for research ethics is that we should still try to navigate the different needs of our research subjects as well as we can. Thus, integrating care into research ethics is not in itself a cure-all for ethical challenges. We must engage in a continuous and conscious negotiation about whom to care, with what cost (and to whom). This means that care is always experiential in nature: there cannot be guidelines on how to care. Yet some choices must made, some actions must be prioritized over others. How to decide? First, I acknowledge that my position as researcher, purposefully engaging the cattle in this research project, creates heightened responsibilities and accountability. This responsibility applies specifically to cows, not to all beings in the cowshed (such as flies) who were not being actively involved in the research through my actions. A second reason is that a crucial part of care-full research ethics is to diminish suffering where possible. Thus, when I had both the capacity and the responsibility to reduce the suffering of cows in my research, it became, in my view, a 'non normative obligation' to do so. Precisely because we cannot care for all things all the time, it becomes especially crucial to take responsibility for the choices we make in deciding who to care for and when.

In the following empirical sections I examine experiences from my research process in attempting to negotiate decision about care-full research ethics in practice. I first explore how to develop the researcher's more-than-human response-abilities in the field, and second, how to make sense of care-full research ethics in relation to the exclusions in knowledge production and analysis.

\section{Care-full research ethics in the field}

I first explore how I navigated the potential of engaging with care-full research ethics in the field, when I was moving around cowsheds with farmers and cows. Conflicts between the needs and interests of humans and cows kept emerging, and all those conflicts could not be placated - some had to be tolerated, while others could only be solved by making difficult ethical decisions on the go, favoring some needs over others. Even the simple goal of not causing physical harm to any being proved difficult, not to mention the grayer ethical terrains that were a constant grievance. These decisions required me to interfere with the practices of both farmers and cows to better respond to their needs.

The farmer asks whether she should urge one older, high-producing cow with bad legs to stand up so that I could look at her body. I say no. I begin to photograph the cow, she's lying down. The farmer leaves to see to a cow that is kicking while being milked by the robot. Suddenly the cow I'm photographing starts to get up; it looks very difficult. As the farmer mentioned, the stalls are obviously much too small for a cow this size. The cow is interested in me, or more likely my camera. I record as she stares at me. I feel a bit bad as it seems the cow got up because of me. (Author's fieldnotes)

In the quote above, the farmer is about to cause some level of physical inconvenience to a cow on my behalf. Similar instances were common. Sick, lame, or old cows were often interesting in terms 
of breeding value, so farmers wanted me to see their bodies properly. It is important to underline that the farmers were not doing this out of malice: they were inconveniencing the cows only to adjust to my needs; to participate in the research project as well as possible. But I was at the same time committed to not harming any of my research subjects. Interfering in such instances was not always successful and it had varying results. Sometimes I was late, and the cow is already getting up. Sometimes I say no too forcefully, and I think the farmer looks at me funny.

The corridors of the cowshed are narrow, it's dark and the ceiling is low. The building is almost a hundred years old. [. . .] We move back and forth: as we encounter a new cow, the farmer stays at the back of the cow while I move to look her in the face. This is not due to how the cows are positioned in the barn. Even when cows are not in stalls, but in the feeding station or just wondering around, the farmer positions herself to the back of the cow. She mentions she recognizes them better that way. I stay to photograph a cow's face and I feel that the farmer becomes restless. Maybe she feels I'm wasting her time. The farmer tries to steer me back into talking about the productive qualities of the cow, and the front of the cow matters little here. I notice that even when talking about legs, which are crucial for structure, the farmer only concentrates on the back legs. (Author's fieldnotes)

And what about even slighter inconveniences? Often, I was concerned with the way farmers would present the bodies of cows to me during fieldwork in the cowshed. I had encouraged farmers to show me 'good breeding' in practice, which meant that cows' bodies were constantly on display and under interrogation. Farmers could do this in any way they liked. Mostly, they approached the cows from behind and presented their hindquarters to me. In preparation for my fieldwork, I had read studies on cattle behavior and learnt that cows dislike being approached from the rear by strangers. Their vision is limited - there is 'blind spot' directly behind them. If you stand in this spot too long, not seeing who is behind them can cause cows stress and even lead them to kick. ${ }^{58}$ I felt it was my responsibility to make sure cows were not afraid of me. This was because my relationship with the cows was different than the farmer's: I was a stranger, while she was a trusted care-taker. Thus, I interfered with the farmers' practices, often by moving to face the cow, to make sure it had a clear view of me. This was not about challenging the farmer's practices, but exploring ways to make sure I was able to respond to the cows' needs in the context of our relationship between researcher and research subject.

I had also read research that indicated that cows enjoy being stroked in the neck. ${ }^{59}$ This practice of moving to the front of the cows disrupted the farmer and created a particular choreography where we moved back and forth around each cow. However, I was not immediately successful in petting and scratching cattle in a way they enjoyed. Eventually, through adjusting my behavior cows begun to tolerate and perhaps enjoy my attentions. I wanted to make sure that cows were able to choose whether they liked to be involved in the research or not physically. If they chose to move away, the farmer and I would examine them at a distance. There were usually a handful of cows in each cowshed that followed me around, waiting to be petted.

My decision to interact more closely with cows was based on cultivating my capacity to respond to the needs of cattle. In this instance, my commitment to care for those involved in my research required me to gather extensive knowledge about their behavior, their likes and dislikes. As explained above, this happened in two ways. First, through educating myself on bovine behavioral science and ethology, and second, through embodied relating with cattle, attempting to move beyond language into cow-centered research practice. ${ }^{60} \mathrm{I}$ perceive these latter encounters with cattle as forms of embodied knowledge production, a praxiographic enquiry into reality. ${ }^{61}$ I see that cows were in very concrete ways cultivating my ability to respond to their needs, and speak back to the research process. To care for other beings is always a fleshy, embodied affair, and the practices of multispecies research ethics - negotiating consent, comfort, harm, asking and answering of 
questions - always also take place in the meetings between bodies. In other words, in multispecies spaces, bodies make research. ${ }^{62}$ At the same time, I argue that multispecies care requires navigating between different knowledges in practices.

Embodied relating also has broader implications. Haraway invites us to share the suffering of animals we study as 'an ethical obligation, a practical problem, and an ontological opening'. This relates to the ethico-political dimension of care, forcing us to train our 'ability to remember and feel', in order to stop 'inequality from becoming commonsensical'. ${ }^{63}$ For me, sharing in the suffering of cows emerged from embodied commonality, revealing structures of power and domination by bringing into focus particular (gendered) bodies in particular spaces. Witnessing various reproductive practices within cowsheds forced me to consider my personal reproductive history. The suddenly narrowing physical distance between me and the cows generated new response-abilities for me and forced me to explore practices of knowing that were not fully, and not only, mine. ${ }^{64}$ Embodied commonalities heightened my sensitivity towards the 'ontological openings' inherent in care, to turning critical attention to the realities and forms of agency that were excluded for cattle.

At times, it was necessary that I interfered with cattle practices to care for my human research subjects in order to maintain respectful and trusting relations with them. These mostly involved verbal involvement in situations in which cows were misbehaving, for example by butting or nibbling at farmers. Furthermore, in one instance, my involvement was requested by a farmer to ensure that an overly eager shepherd dog was not harassing a sick cow. Attending to care-full research ethics did not therefore always involve a conflict between the needs of farmers and cows, but contributed to caring for both. ${ }^{65}$ However, when tensions are present, acts of care may have various (unexpected) consequences. For example, interfering with farmers' material or discursive practices carried concrete risks for me as a researcher: voicing (or performing acts of) disagreement could potentially lead participants to police their behavior and language in ways that impacted the data. The potential loss of rapport associated with these acts could also impact further access into the field. Here, the non-innocence of care was present, requiring constant reflexivity on who is being cared for, why, and at what cost to whom $?^{66}$

These empirical examples showcase that cultivating care-full research ethics in practice can take shape as various material interferences. These practices make visible my attempts at caring for my research subjects, sometimes including active involvement, in order to cultivate my capacity to respond to the needs of my research subjects. I perceive these material interferences as forms of attentive experimentation into ethical practice. ${ }^{67}$ This experimental quality means that interferences can also go awry, and their impacts can be unexpected. Furthermore, this process will always involve the researcher putting herself at risk. In each act of interference in the field, something will be lost, while something will be gained. As a result, these acts shape how relations congeal between the researcher and research subjects, requiring me to take responsibility for actions that might exclude certain relations for the benefit of others. These tensions relate specifically to practice of caring in fieldwork with two divergent groups of research subjects. Yet I believe that material interferences have potential to work as an exploration into the coexistence of trust and tension - as well as difference and similarity.

\section{Care-full research ethics and knowledge politics}

Crucially, the ethical response-abilities of researchers also extend beyond the immediate somatic relations ${ }^{\prime 68}$ between the researcher and the research subjects, into thinking, writing, and analysis. In attempting to put the 'ethics of exclusion' into practice, we need to take care to stay humble about the limits of our knowledge. Relying only on the knowledge gathered from encounters with 
others - even while taking care to think with them rather than for them in our analysis - can lead us to overlook what is left immaterialized or unimagined in our relations with them. This includes a responsibility to explore what we know about those we study, how we know it, and why we know it. Here, I draw on the notion of 'thinking with care' developed by Donna Haraway and later by Maria Puig de la Bellacasa. Thinking with care is an attempt to engage with worlds by making them thicker than they first seem by adding layers to them. Puig de la Bellacasa ${ }^{69}$ underlines that in this work, the predominant word is 'and' rather than 'either' or 'or'. For me, such critical curiosity is a way to take responsibility for the stories I tell about my research subjects.

As care is never innocent, thinking with care cannot be either. Thus, this type of critical curiosity can require interference into existing thinking and knowing, both for myself and others. Farmers have much better capacities than cows to help me to think with them, rather than for them. Thus, I felt it was especially important to stay attentive to the invisibilities, disappearances, and exclusions related to cows, whose abilities in this regard are in various ways restricted. In practice, this took the shape of exploring what has been neglected in our knowledge about cattle, which is largely produced for the context of farming. This was an attempt to make visible the 'agential cuts' between humans and cattle, trying to catch glimpses of the various bovine histories, worlds, and cultures that are excluded in our entanglements with them. The question becomes, do the stories I tell continue to foreclose worlds and relations, or our open avenues for new entanglements? I introduce three practices that I found useful in cultivating my capacity to add to the realities and knowledges about cattle.

The first, obvious step was to turn to the humans inhabiting shared multispecies realities with cattle. Jocelyn Porcher encourages scholars to always think of 'humans and animals, farmers and their beasts, together', ${ }^{70}$ as farmers can help us figure out more intriguing questions we should be asking about farm animals. ${ }^{71}$ Farmers are of course an important access point into studying cows - in very material terms, giving me permission to enter the cowshed, but also in terms of helping me gain insights into bovine subjectivities. In myriad ways, farmers helped to add to realities and stories about cattle through my research. Farmers explained the behavior of their cows in the cowshed, working as an interlocutor between me and the cows, and helping me to respond to the needs of the individual animals. Farmers helped me to ask better questions about cows and see things that would have easily remained invisible to me. Although my questions did not always resonate with farmers (for example about cattle agency), farmers quickly put an end to any ideas about cows as passive or mechanistic, and unveiled the endlessly intriguing world of cattle practices and cultures. This happened tacitly, for example through their anecdotes about individual cattle personalities and behavior. This also relates to Moore and Kosut's ${ }^{72}$ call for daring to ask questions about other animals that may seem ludicrous to others. At the same time, it needs to be underlined that it makes little sense to perceive humans and cows on dairy farms as anything but deeply entangled. Thinking with cows requires thinking with farmers - and the same is true the other way around as well. Thinking with care is not individual, but a relational pursuit.

On one farm I visited, I thought the cows seemed particularly well cared for. Yet the farmer was constantly apologizing to me for how the cows looked. The cowshed was too small, she said, and it caused many welfare issues. She showed me bumps I hadn't noticed, on the hips and backs of some cows caused by the cows hitting the stall when they got up. (Author's fieldnotes)

In the quote above, the farmer is showing me how her breeding goal - producing larger and more robust cows, ones that do well in livestock shows - is in conflict with the infrastructure of her farm. She has applied for permits to build a larger cowshed, but has not yet got one. The big cows 
are uncomfortable in the old cowshed. This relational and contextual understanding made me more response-able to similar issues on other farms, helping me to ask better questions about cattle and their welfare.

At the same time, human research subjects were not given authority to decide which questions matter in relation to bovine research subjects in my work. As mentioned, this is an attempt to add to the realities studied by cultivating a critical curiosity towards those I hoped to thinkwith (both farmers and cattle). Moore and Kosut ${ }^{73}$ specifically encourage scholars to re-evaluate human-centric approaches in multispecies research, being open to un-learning taken-for-granted assumptions about research subjects. This is a practical way of exploring both disentanglements and entanglements between humans and other animals. Farmers and cows know each other within the context of dairy farming. I felt it was important to ask what became invisible or excluded in this context. For example, I found that the contextualization of certain productionrelated diseases (such as mastitis) was often framed in a way that naturalized them as part of the 'bovine condition,' rather than of intensive milk production. This example reveals the specific agential cuts on which dairy farming is built. As a researcher I wanted to take care not to take these cuts as given.

The second step in attempting to add to the realities I studied signified an interdisciplinary engagement with animal science: educating myself on relevant research in the field of ethology. As mentioned, this was useful in contributing directly to my capacities to respond to the needs of cattle, for example, through learning to read animals' body language. At the same time, a critical curiosity towards the context in which knowledge is produced is also necessary in terms of animal science. Specifically in terms of cattle, the questions we as society ask of them tend to be framed in terms of their relevance for livestock production. This necessarily influences our knowledge, and even more importantly, our imagination.

The third step in better contextualizing the knowledge I had gathered about the realities on dairy farms was to learn to know cattle also outside dairy farming. I turned to other empirical sites, visiting two farm animal sanctuaries, one in Finland and one in southern England. Observation and interviews in these spaces led me to re-evaluate certain aspects of knowledge about cattle and provided me with more comprehensive understanding about the dis-entanglements inherent in the realities on dairy farms. Parallel understanding emerged about cattle health, behavior, social structure, tolerance to pain or different temperatures, and even the way their winter fur grows. For example, in the animal sanctuaries, animal play emerged as an important part of daily cattle lives, as well as an indicator of social structures. In the farm context I found play behavior to emerge mostly in relation to calves, heifers, and dry cows - the animals with the smallest udders and least to do in terms of 'work'. For the milk-producing cows play can be more difficult, as the udder is heavy and play behavior can lead to ruptures. By simply focusing on the relations on farms, it would be difficult to understand what exactly was being excluded through less focus on play. ${ }^{74}$

I perceive these three practices as analytical interferences towards exploring what might be excluded for cattle in the spaces I studied. Much of the information produced and presented about cattle rests on reinforcing the specific agential cuts performed within dairy production. Interfering with these accounts can open questions such as what kind of agency is excluded for cattle; what is set beyond the realm of imagination for them? Crucially, such questions are not about placing moral judgment on the agential cuts performed, but taking care for not naturalizing these cuts, and taking responsibility for broadening and multiplying perspectives. Following Haraway $^{75}$, it matters what knowledge know knowledge, and what stories tell stories. Analytical interferences are an attempt to take responsibility for the realities and relations that are reinforced or re-imagined within research. 


\section{Conclusion}

In this paper I have argued that care might be a useful lens for making sense of multispecies research ethics, when informed also by the exclusions in relations. This requires concrete tools and methods, such as novel approaches to empirical work as well as critical perspectives towards the data and material used. I examine these as empirical and analytical interferences. Empirical interferences contribute to more inclusive fieldwork practices based on cultivating the researcher's capacity to respond to the needs and agency of different research subjects, while analytical interferences into knowledge production attempt to tease out excluded relations to add to the realities studied and the existing stories told about them.

Crucially, this paper is not intended as a guideline for how to care. Furthermore, the examples I have recounted are not meant to work as methodological checklists for all (or any) multispecies research. Instead of developing novel methods for multispecies spaces, I propose that social scientific research involving humans and other animals could benefit from a more care-full ethical approach. Crucially, I suggest that telling more informed stories about other animals and humananimal relations cannot only be achieved by developing better methods. Embodied methods, for example, can be important and useful in research involving multiple species. At the same time, instead of attempting to 'crack' other animals, we will do well to remember that other animals have suffered and continue to suffer immensely as the result of our persistent desire to know them - and as the result of our assumption that we do. Through care for other animals we may learn to accept their inherent unknowability, succumbing to their potential to surprise us, while exploring less intrusive and more ethical ways of knowledge production.

Finally, I want to draw attention to the suggestion made by Hollin et al. ${ }^{76}$ that the ethics of exclusion moves discussion beyond stating that 'things could be otherwise', into taking responsibility for how things congeal as they are. In the context of research ethics and this paper, I perceive this responsibility to lie in the kind of stories I choose to tell through my research. This requires taking responsibility for the choices made in the research process as well is in representation and writing - asking whether my research reinforces the agential cuts observed or opens space for exploring what is excluded by and in them. It needs to be underlined that the point is not to pass judgment on the agential cuts performed. Instead, including also exclusions in the realm of ethical responsibilities turns attention to coming to terms with all of the consequences of the inevitable death that is involved in living. Furthermore, it urges us to explore the transformative ethico-political possibilities of our entangled pasts, presents and futures. ${ }^{77}$

I argue that this thinking is particularly fruitful for multispecies research in farm contexts, as it does not assume predetermined positions or judgments, but is nonetheless able to engage in critical ethical evaluation that remains mindful of the contextual distribution of power. Ethics of exclusion may open space for thinking-with both humans and animals in farm spaces, without thinking-for either of them. I suggest that this approach has potential to shift the focus of analyzing multispecies relations from criticism and confrontation to opening space for more inclusive, overlapping, and intertwining stories.

This requires making space for the coexistence of trust and critical tension in the research practice. Rather than promising harmony or innocence, such research ethics are committed to figuring out how attending to (dis)entanglements could be transformed into more hopeful and liveable states in the here and now.

\section{Acknowledgements}

I wish to thank all the cows and humans on the farms and sanctuaries I visited - they all contributed to writing this paper. I am also very grateful to Chris Bear for his encouragement and insightful comments on various early drafts of this paper. 


\section{Funding}

The author disclosed receipt of the following financial support for the research, authorship, and/or publication of this article: The writing of this paper has been funded by the Doctoral School of the University of Eastern Finland.

\section{ORCID iD}

Annika Lonkila (iD) https://orcid.org/0000-0002-2637-396X

\section{Notes}

1. T.Hodgetts and J.Lorimer, 'Methodologies for Animals' Geographies: Cultures, Communication and Genomics', cultural geographies, 22(2), 2015, pp. 285-95; J.Lorimer, 'Moving Image Methodologies for More-than-Human Geographies', cultural geographies, 17(2), 2010, pp. 237-58; P.RichardsonNgwenya, 'Performing a More-than-Human Material Imagination During Fieldwork: Muddy Boots, Diarizing, and Putting Vitalism on Video', cultural geographies, 21(2), 2014, pp. 293-9; M.Bastian, O.Jones, N.Moore and E.Roe (eds), Participatory Research in More-than-Human Worlds (London: Routledge, 2016); L.Hamilton and N.Taylor, Ethnography After Humanism : Power, Politics and Method in Multi-Species Research (London: Plagrave Macmillan, 2017).

2. N.Castree and C.Nash, 'Posthuman Geographies', Social \& Cultural Geography, 7(4), 2006, pp. 501-4; J.Lorimer, 'Posthumanism/Posthumanistic Geographies', in R.Kitchin and N.Thrift (eds), International Encyclopedia of Human Geography, Vol. 8 (Oxford: Elsevier, 2009), pp. 344-54.

3. B.Braun, 'Environmental Issues: Writing a More-than-Human Urban Geography', Progress in Human Geography, 29(5), 2005, pp. 635-50; S.Whatmore, 'Materialist Returns: Practising Cultural Geography In and For a More-than-Human World', cultural geographies, 13, 2006, pp. 600-9; C.Wilbert and C.Philo (eds), Animal Spaces, Beastly Places: New Geographies of Human-Animal Relations (London and New York: Routledge, 2000); R.-C.Collard and K.Gillespie, 'Doing Critical Animal Geographies: Future Directions', in R.-C.Collard and K.Gillespie (eds), Critical Animal Geographies: Politics, Intersections and Hierarchies in a Multispecies World (London and New York: Routledge, 2015), pp. 203-12; H.Buller, 'Animal geographies I', Progress in Human Geography, 38(2), 2014, pp. 308-18; Buller, 'Animal geograhies II: Method', Progress in Human Geography, 39(3), 2015, pp. 374-84; Buller, 'Animal geographies III: Ethics', Progress in Human Geography, 40(3), 2016, pp. 422-30.

4. D.Haraway, The Companion Species Manifesto: Dogs, People, and Significant Otherness (Chicago: Prickly Paradigm Press, 2003), p. 307.

5. Hamilton and Taylor, 'Ethnography after Humanism'.

6. B.Greenhough and E.Roe, 'From Ethical Principles to Response-Able Practice', Environment and Planning D: Society and Space, 28(1), 2010, pp. 43-5; M.M.Donald, 'When Care is Defined by Science: Exploring Veterinary Medicine through a More-than-Human Geography of Empathy', Area, 51(3), 2018, pp. 470-8; G.Davies, 'Caring for the Multiple And Multitude: Assembling Animal Welfare And Enabling Ethical Critique', Environment and Planning D, 30, 2012, pp. 623-38.

7. Greenhough and Roe, 'From Ethical Principles to Response-Able Practice', citing S.Whatmore, Dissecting the Autonomous Self: Hybrid Cartographies for a Relational Ethics, Environment and Planning D: Society and Space, 15(1), pp. 37-53.

8. Hamilton and Taylor, Ethnography after Humanism. p. 147.

9. Later, I also visited two farm animal sanctuaries, one in Finland and one in the UK, to interview caretakers and observe the animals.

10. Finnish National Board on Research Integrity, The Ethical Principles of Research with Human Participants and Ethical Review in the Human Sciences in Finland. 10, 2019, <https://www.tenk.fi/en/ tenk-guidelines $>$ (26 November 2019).

11. Act on the Protection of Animals Used for Scientific or Educational Purposes, 497/2013.

12. Instructions for Researchers.. Viikki Campus Research Ethics Committee, 8, 2018, <https://www. helsinki.fi/sites/default/files/atoms/files/eettisen_lausunnon_hakuohje_muokattu_20180821.pdf> (26 November 2019). 
13. R.Edwards and M.Mauthner, 'Ethics and Feminist Research: Theory and Practice', in M.Mauthner, M.Birch, J.Jessop and T.Miller (eds), Ethics in Qualitative Research (London: SAGE, 2002), pp. 14-31.

14. N.Noddings, Caring: A Feminine Approach to Ethics and Moral Education (Berkeley: University of California Press, 1984).

15. C.Gilligan, In a Different Voice: Psychological Theory and Women's Development (Cambridge, Massachusetts: Harvard University Press, 1982).

16. J.Tronto, Moral Boundaries: A Political Argument for an Ethics of Care (New York: Routledge, 1993).

17. J.Popke, 'Geography and Ethics: Everyday Mediations Through Care and Consumption', Progress in Human Geography, 30(4), 2006, pp. 504-12; S.Bowlby, 'Recognizing the Time-Space Dimensions of Care: Caringscapes and Carescapes,' Environment and Planning A: Economy and Space, 44, 2012, pp. 2101-18.

18. M.Puig de la Bellacasa, Matters of Care: Speculative Ethics in More than Human Worlds (Minneapolis: University of Minnesota Press, 2017).

19. J.Donovan, 'Feminism and the Treatment of Animals: From Care to Dialogue', Signs, 31(2), 2006, pp. 305-29.

20. B.Fisher and J.Tronto, 'Toward a Feminist Theory of Caring', in E.K.Abel and M.K.Nelson (eds) Circles of Care: Work and Identity in Women's Lives (Albany: State University of New York Press, 1990), pp. 40-62.

21. Fisher and Tronto, Towards a Feminist Theory of Caring, p. 40.

22. Puig de la Bellacasa, 'Nothing Comes Without Its World': Thinking with Care', The Sociological Review, 60(2), 2011, pp. 197-216.

23. D.Conradson, Space of Care in the City: The Place of a Community Drop-in Centre', Social \& Cultural Geography, 4(4), 2003, pp. 507-25, p. 508.

24. B.Latour, We Have Never Been Modern (Cambridge, Massachusetts: Harvard University Press, 1993); T.Schatzki 'Practice theory as flat ontology' in Spaargaren et al. (eds) Practice Theory and Research (London: Routledge, 2016), pp. 28-42.

25. R.Nimmo, 'Apiculture in the Anthropocene: Between Posthumanism and Critical Animal Studies', in Human-Animal Research Network (HARN) Editorial Collective (eds), Animals in the Anthropocene: Critical Perspectives on Non-human Futures (Sydney: Sydney University Press, 2015), pp. 177-99.

26. Popke, Geography and Ethics: Spaces of Cosmopolitan Responsibility', Progress in Human Geography, 31(4), 2007, pp. 509-18.

27. Donovan, 'Feminism and the Treatment of Animals', p. 306.

28. Donovan, 'Feminism and the Treatment of Animals', p. 306.

29. J.Donovan and C.Adams (eds), Beyond Animal Rights: A Feminist Caring Ethic for the Treatment of Animal (Continuum, 1996).

30. G.Hollin, I.Forsyth, E.Giraud and T.Potts, '(Dis)entangling Barad: Materialisms and Ethics', Social Studies of Science, 47(6), 2017, pp. 918-41.

31. Puig de la Bellacasa, Nothing Comes Without Its World.

32. V.Lawson, 'Geographies of Care and Responsibility', Annals of the Association of American Geographers, 97(1), 2007, pp. 1-11; D.Massey, 'Geographies of Responsibility,' Geografiska Annaler: Series B, Human Geography, 86(1), 2004, pp. 5-18. P.Raghuram and C.Madge, 'Rethinking Responsibility and Care for a Postcolonial World', Geoforum, 40(1), 2009, pp. 5-13.

33. J.Carmalt, 'Human Rights, Care Ethics and Situated Universal Norms', Antipode, 43(2), 2011, pp. 296-325, V.Lawson, 'Geographies of Care and Responsibility', Annals of the Association of American Geographers, 97(1), 2007, pp. 1-11.

34. J.Cottingham, 'Caring at a Distance: (Im)partiality, Moral Motivation and the Ethics of RepresentationPartiality, Distance and Moral Obligation', Ethics, Place \& Environment 3(3), 2000, pp. 309-313.

35. R.Garner, 'Political Ideologies and the Moral Status of Animals', Journal of Political Ideologies, 8(2), 2003, pp. 233-46, p. 241.

36. Donovan, 'Feminism and the Treatment of Animals'.

37. A.Mol, The Body Multiple: Ontology In Medical Practice (Durham and London: Duke University Press, 2002); A.Mol, I.Moser and J.Pols (eds), Care in Practice: On Tinkering in Clinics, Homes, and Farms (Bielefeld: Transcript, 2010); Puig de la Bellacasa, 'Matters of Care'. 
38. Mol et al., 'Care: Putting Practice into Theory', in Mol et al. (eds) Care in Practice: On Tinkering in Clinics, Homes, and Farms, pp. 7-25.

39. T.van Dooren, 'A Day With Crows: Rarity, Nativity and the Violent-Care of Conservation', Animal Studies Journal, 4(2), 2015, pp. 1-28.

40. Puig de la Bellacasa, 'Matters of Care'; Barad, Meeting the Universe Halfway, p. 2.

41. Greenhough \& Roe, 'From ethical principles to response-able practice', p. 45.

42. Greenhough \& Roe, 'From ethical principles to response-able practice'.

43. It is not possible to explore Barad's theory here at length, but see K.Barad, 'Posthuman Performativity: Toward an Understanding of How Matter Comes to Matter', Signs 28(3), 2003, pp. 801-31 and K.Barad, Meeting the Universe Halfway: Quantum Physics and the Entanglement of Matter and Meaning (Durham: Duke University Press, 2007).

44. Hollin et al., '(Dis)entangling Barad', p. 21.

45. Hollin et al., '(Dis)entangling Bard', p. 22; van Dooren, 'Care', Environmental Humanities, 5, 2014, pp. $291-4$.

46. E.Giraud and G.Hollin, 'Care, Laboratory Beagles and Affective Utopia', Theory, Culture and Society, 33(4), 2016, pp. 27-49.

47. R.Edwards and M.Mauthner, 'Ethics and Feminist Research: Theory and Practice'; A.Bingley, 'Research Ethics in Practice', in L.Bondi (ed), Subjectivities, Knowledges and Feminist Geographies: The Subjects and Ethics of Social Research (Lanham, MD: Rowman \& Littlefield, 2002), pp. 208-22, p. 209.

48. R.Edwards and M.Mauthner, 'Ethics and Feminist Research: Theory and Practice'.

49. M.Guillemin and L.Gillam, 'Ethics, Reflexivity, and "Ethically Important Moments" in Research', Qualitative Inquiry, 10(2), 2004, pp. 261-80.

50. Edwards and Mauthner, 'Ethics and Feminist Research: Theory and Practice'.

51. van Dooren, 'Care', p. 293.

52. T.van Dooren, 'A Day With Crows'.

53. Haraway, 'When Species Meet'.

54 L.J.Moore and M.Kosut, 'Among the Colony: Ethnographic Fieldwork, Urban Bees and Intra-species Mindfulness', Ethnography, 15(4), 2014, pp. 516-39.

55. I.Stengers, Cosmopolitics I (Minneapolis: University of Minnesota Press, 2010); I.Stengers, In Catastrophic Times: Resisting the coming Barbarism (Open Humanities Press, 2015).

56. Haraway, Staying with the Trouble: Making Kin in the Chthulucene (Durham, NC: Duke University Press, 2016), p. 105.

57. Puig de la Bellacasa, 'Nothing comes without its world', p. 204, emphasis in original.

58. T.Grandin, 'Principles for Low Stress Cattle Handling', Paper presented at the Proceedings, The Range Beef Cow Symposium XVI, Greeley, Colorado, 14-16 December, 1999.

59. C.Schmied, X.Bovin and S.Waiblinger, 'Stroking Different Body Regions of Dairy Cows', Journal of Dairy Science 91(2), 2008, pp. 596-605.

60. On bee-centered research practices, see Moore and Kosut, 'Among the colony'.

61. Mol, 'The Body Multiple', p. 32.

62. Haraway, 'When Species Meet'.

63. Haraway, 'When Species Meet', pp. 75-84.

64. Buller, 'Animal Geographies II; Barad, Posthumanist performativity', p. 829

65. As mentioned, I saw my ethical responsibilities to lie specifically with the farmers and cows - whom I had chosen to involve in my study as research subjects. I would of course attempt to try to make sure my research did not cause harm to any of the human farm hands, or flies, or dogs I encountered. Nonetheless those beings were not being sought out me, rather they wondered in and out of the research setting on their own will.

66. van Dooren, 'A Day With Crows'.

67. Mol, 'The Body Multiple'.

68. Hollin et al., '(Dis)entangling Barad'.

69. Puig de la Bellacasa, 'Nothing comes without its world', p. 201. 
70. V.Despret, What Would Animals Say If We Asked the Right Questions? (Minneapolis: University of Minnesota Press, 2016).

71. Despret, What Would Animals Say, p. 178.

72. Moore and Kosut, 'Among the colony'.

73. Moore and Kosut, 'Among the colony'.

74. S.Held and M.Spinka, Animal Play and Animal Welfare, Animal Behavior, 81(5), 2011, pp. 891-9.

75. Haraway, 'Staying with the Trouble', p. 34.

76. Hollin et al., '(Dis)entangling Barad', p. 20.

77. D.Haraway, 'SF: Science Fiction, Speculative Fabulation, String Figures, So Far', Ada: A Journal of Gender, New Media, and Technology, 3, 2013.

\section{Author biography}

Annika Lonkila (MSc) is a doctoral student at the University of Eastern Finland. Her PhD explores the implications of introducing genomic livestock breeding practices in the Finnish dairy industry. She works as a Researcher at the Finnish Environment Institute, exploring transition towards a more sustainable and fair food system. 